\title{
Measuring ASEAN Rice Non-Tariff Measures (NTMs) and Its Impact on Indonesian Food (Rice) Security
}

\section{Iwan Hermawan ${ }^{1}$}

\author{
${ }^{1}$ University of Indonesia, Indonesia, e-mail: iwan.hermawan@dpr.go.id
}

\begin{abstract}
In this research, we calculated ASEAN rice non-tariff measures (NTMs) and its impact on Indonesian food (rice) security. To assess whether NTMs facilitate or impede rice trade across countries in ASEAN region, Gravity Model was applied with Pseudo Poisson Maximum Likelihood (PPML) method. It allowed calculating implied ad valorem equivalents of NTMs. The data was sourced from World Bank, Comtrade, World Integrated Trade Solution (WITS), Centre d'Études Prospectives et d'Informations Internationales (CEPII), and so on. The Gravity Model also used panel data type with time series year 2013-2015 and cross section 16 country/region. Rice type in this research based on HS Code 100630. Second approach, we linked and used Gravity Model result into Global Trade Analysis Project (GTAP) Model, to examine the impact of ASEAN rice NTMs on Indonesian food security. A standard GTAP Model was aggregated by 19 sectors and 16 countries/regions. The results showed that (a) Brunei Darussalam, Thailand, and Cambodia have the highest rice NTMs based on estimation of tariff equivalent calculation and (b) imposing ASEAN rice NTM lead to negative effects on Indonesian food security. Even though rice NTMs would improve rice availability, especially in rice production, but negatively on its utility and accessibility. There was trade-off between NTMs and trade liberalization policy, and the government should be wise and careful to impose rice NTMs as temporary policy.
\end{abstract}

Keywords: NTMs, rice trade, ASEAN, Gravity Model, GTAP Model

\section{Introduction}

Non-tariff measures (NTMs) or sometimes called non-tariff barriers (NTBs) are policy measures, other than tariffs, which are coming in the way of open trade in agricultural commodities. NTMs do not necessarily imply illegitimate measures and/or restrictive implications on trade. In fact, WTO allows the application of NTMs in particular circumstances. In some cases, the application of legitimate NTMs could even increase trade by giving more information and certainty to producers and consumers. However, some NTMs are barriers as they are implemented with specific protectionist purposes that negatively affect trade. In addition, many NTMs are not transparent since they are hidden in regulations or appear as disguised policies (APEC, 2014). It is not surprising if some expert said that NTMs may become worse implication than tariff barrier.

NTMs have also been imposed on rice trade. Some cases occur, for example imposing Sanitary Phytosanitary (SPS) (India, Viet Nam) (Goyal, et al, 2017), import license (EU), export subsidy (EU, USA), monitors import and procures rice (India) (Deb, 2007), and import quota (Indonesia). Detail all NTM type, include technical and non-technical barrier, is classified by UNTAD (Table 1). At least there are 16 NTMs have potential to disrupt rice trade. Those policies are to ensure rice availability and affordability for its citizens. This is because rice has a vital role in national food security and also political stability in most Asian country, include Indonesia.

NTMs in Indonesia are tariff rate quota (not yet applied), state trading, and state procurement via The Indonesia Logistics Bureau (Bulog), which are imposed mainly on rice, particularly medium quality. Even though, rice quantity is no more than 5 to 10 percent of domestic production, but it often generates a rowdy. Thailand and Viet Nam are regularly as rice import source for Indonesia, if they also enforce thigh NTMs, we could not imagine what is the impact on Indonesia food security. In light of decreasing rice tariffs resulting from multilateral, regional, and bilateral trade agreements as well as preferential trade arrangements, trade flows of rice are increasingly being determined by 
NTMs. NTMs take the form of a range of measures that have incidences at the border and can impede trade. The main objective of this research is to analyze the impact of rice non-tariff measures (NTMs) in ASEAN country on Indonesian food security.

Table 1. Classification of Non-Tariff Measures

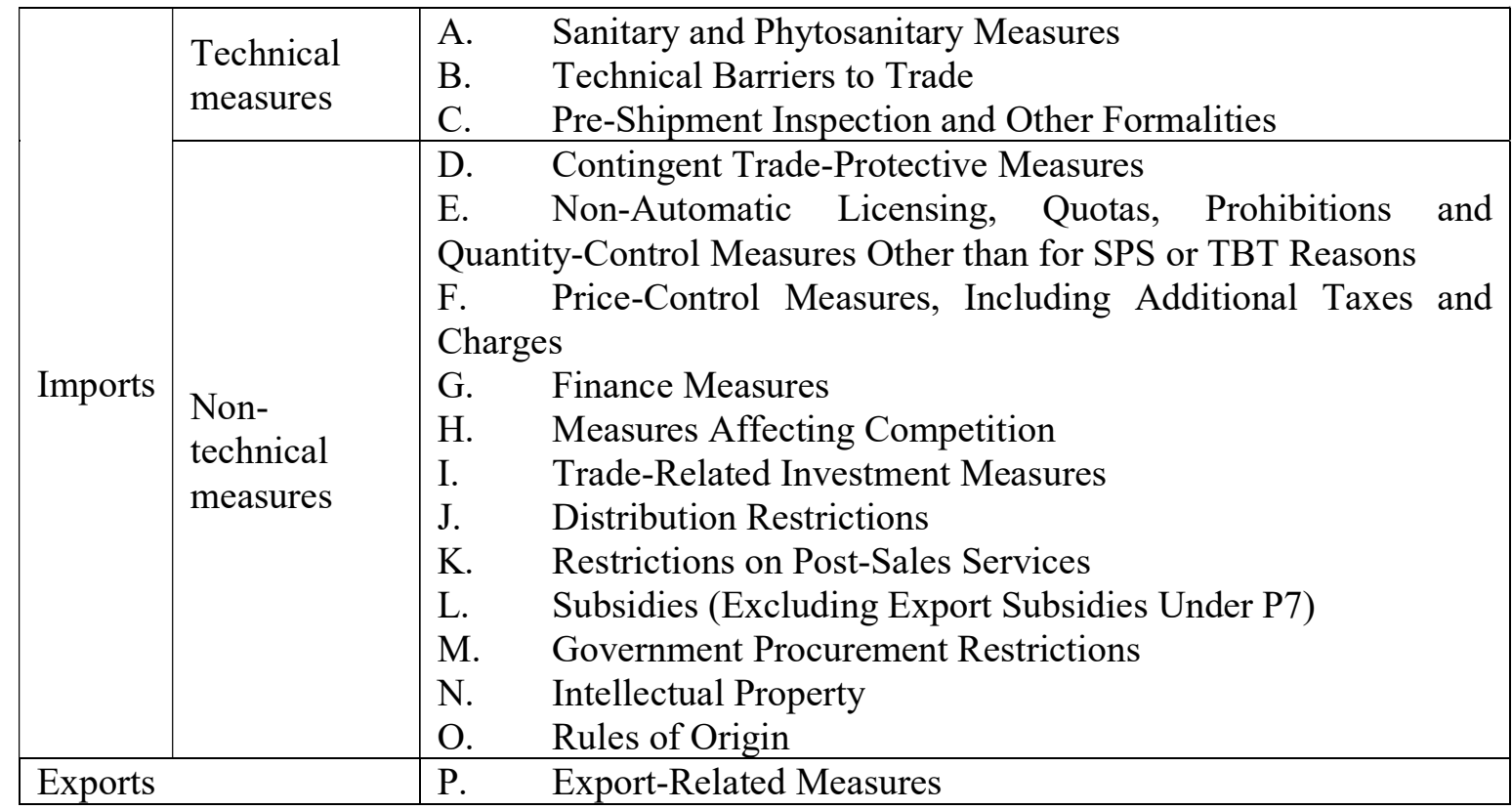

Source: UNCTAD, 2015.

There are so many examples of studies which elaborate NTMs, for example Gao, et al (2016), Guordon (2014), O'Callaghan and Uprasen (2008), Marks (2017), and so on. They elaborate those NTMs issues from many viewpoints and approach. But there remains significant scope to refine the methodologies (Walmsley and Minor, 2015). Our approach uses econometric estimates of the effect NTMs on imports into all country, particularly major ASEAN countries, using a gravity model framework. We then use these econometric estimates to simulate NTMs using Global Trade Analysis Project (GTAP) model.

\section{Research Methodology}

In this research, we used secondary data. The data was divide into 2 group, first for Gravity Model, there was panel data with time series year 2013-2015 and cross section 16 country/region who rice trading, namely Indonesia, Malaysia, Thailand, Brunei Darussalam, Singapore, Philippines, Viet Nam, Cambodia, Laos, China, Japan, South Korea, South Asia, Sub Sahara Africa, East Asia, Middle East Asia, and other country/region. Rice type in this research based on HS Code 100630. Those data came from, which are World Bank (World Development Indicators), Comtrade, World Integrated Trade Solution (WITS), Centre d'Études Prospectives et d'Informations Internationales (CEPII), International Monetary Fund (IMF), International Labor Organization (ILO), and so on. Data processing in Gravity equation employed Stata 13 software. And second for GTAP Model, the data was sourced from GTAPAgg2 (GTAP 9.0), released year 2016, and processed by RunGTAP 3.62 software.

The analysis method applied NTM approach through Gravity Model and its impact on Indonesian food security used GTAP Model. NTM approach based on residual, as practiced by Wall (1999) and Park (2002). It is assumed that difference between actual and potential trade flows of the country implies trade barriers. The potential trade flows can be obtained from Gravity estimation. The value 
of tariff equivalent is very sensitive to the value of elasticity of substitution $(\sigma)$. This study uses value of elasticity from the GTAP database.

The final form of gravity specification is presented in equation (1), where the sub-index $i$ and $j$ refer to the exporter and importer country, respectively, whilst $t$ refers to the year:

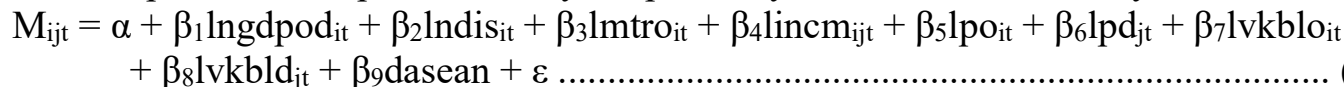

Where:

$\mathrm{M}_{\mathrm{ijt}} \quad$ : imports of country $\mathrm{j}$ from country $\mathrm{i}$ (mio USD).

gdpod $_{\text {it }} \quad:$ ratio between GDP of origin with GDP of destination country (mio USD)

disit : distance between the capital cities of the importing and exporting country $(\mathrm{km})$, the data are obtained from CEPII.

mtro $_{i t} \quad:$ import tariffs imposed by importing country $\mathrm{j}(\%)$.

incm $_{\text {it }} \quad:$ income per capita between origin and destination country.

po $_{i t}, \mathrm{pd}_{\mathrm{it}} \quad:$ composite price indices in country $\mathrm{i}$ and $\mathrm{j}$. They are proxied by the consumer prices index $(2000=100)$, the data are compiled from the International Monetary Fund (IMF).

vkblo $_{i t}, \operatorname{vkbld}_{j t}$ : capital labor ratio of country $i$ and $j$, respectively. The data of capital are proxied by VKB (value of beginning capital stocks) from GTAP database 9.0 (mio USD), while the data of labor forces are obtained from International Labor Organization (ILO).

dasean : dummy ASEAN.

$\alpha \quad:$ intercept.

$\beta_{1}-\beta_{8} \quad:$ parameter estimation.

$\varepsilon \quad:$ error term.

Along with zero-observations and the problem of heteroscedasticity often occurs in trade data, the Pseudo Poisson Maximum Likelihood (PPML) is a robust approach (Silva and Tenreyro, 2006). This approach has been used in a number of estimations of Gravity equations, such as Westerlund and Wilhelmsson (2011), and Akhvlediani and Śledziewska (2017). PPML employed here was PPML fixed effect and to ensure PPML was robust, this research conducted the Ramsey Regression Equation Specification Error Tests (RESET). Next step, result running data from Gravity Model is injected to GTAP Model.

GTAP Model is a comparative static model and its percentage changes are able to illustrate the changes before and after policy making. GTAP Model explicitly accommodated the margin transportation international and bank global as a form of intermediation of investment and savings of the world. Consumer demand system was expected by Constant Difference of Elasticities (CDE) to catch the sensitivity of price and income differences cross-border. In addition, the flow of goods in international trade followed Armington Model, in which any product was differentiated by its origin. Each domestic product was assumed has imperfect substitution. 
Table 2. Region Aggregation Based on GTAP Database

\begin{tabular}{|c|c|c|c|}
\hline No. & Code & Description & Comprising \\
\hline 1. & CHINA & China & chn \\
\hline 2. & JAP & Japan & jpn \\
\hline 3. & KORS & South Korea & kor \\
\hline 4. & $\begin{array}{l}\text { BRUNE } \\
\text { ID }\end{array}$ & Brunei Darussalam & brn \\
\hline 5. & CMD & Cambodia & $\mathrm{khm}$ \\
\hline 6. & IDN & Indonesia & idn \\
\hline 7. & LAOS & Laos & lao \\
\hline 8. & MYS & Malaysia & mys \\
\hline 9. & PIL & Philippines & phl \\
\hline 10. & SIN & Singapore & sgp \\
\hline 11. & THAI & Thailand & tha \\
\hline 12. & VIE & Viet Nam & vnm \\
\hline 13. & SOAS & $\begin{array}{l}\text { South Asia (Bangladesh; India; Nepal; Pakistan; Sri Lanka; } \\
\text { Rest of South Asia) }\end{array}$ & $\begin{array}{l}\text { bgd ind npl pak lka } \\
\text { xsa }\end{array}$ \\
\hline 14. & SSA & $\begin{array}{l}\text { Sub-Sahara Africa (Benin; Burkina Faso; Cameroon; Cote } \\
\text { d'Ivoire; Ghana; Guinea; Nigeria; Senegal; Togo; Rest of } \\
\text { Western Africa; Central Africa; South Central Africa; } \\
\text { Ethiopia; Kenya; Madagascar; Malawi; Mauritius; } \\
\text { Mozambique; Rwanda; Tanzania; Uganda; Zambia; } \\
\text { Zimbabwe; Rest of Eastern Africa; Botswana; Namibia; South } \\
\text { Africa; Rest of South African Customs) }\end{array}$ & $\begin{array}{l}\text { ben bfa cmr civ gha } \\
\text { gin nga sen tgo xwf } \\
\text { xcf xac eth ken mdg } \\
\text { mwi mus moz rwa } \\
\text { tza uga zmb zwe } \\
\text { xec bwa nam zaf } \\
\text { xsc }\end{array}$ \\
\hline 15. & MEAS & $\begin{array}{l}\text { Middle East Asia (Bahrain; Iran Islamic Republic of; Israel; } \\
\text { Jordan; Kuwait; Oman; Qatar; Saudi Arabia; Turkey; United } \\
\text { Arab Emirates; Rest of Western Asia; Egypt; Morocco; } \\
\text { Tunisia; Rest of North Africa) }\end{array}$ & $\begin{array}{l}\text { bhr irn isr jor kwt } \\
\text { omn qat sau tur are } \\
\text { xws egy mar tun xnf }\end{array}$ \\
\hline 16. & ROTW & $\begin{array}{l}\text { Other (Australia; New Zealand; Rest of Oceania; Hong Kong; } \\
\text { Mongolia; Taiwan; Rest of East Asia; Rest of Southeast Asia; } \\
\text { Canada; United States of America; Mexico; Rest of North } \\
\text { America; Argentina; Bolivia; Brazil; Chile; Colombia; } \\
\text { Ecuador; Paraguay; Peru; Uruguay; Venezuela; Rest of South } \\
\text { America; Costa Rica; Guatemala; Honduras; Nicaragua; } \\
\text { Panama; El Salvador; Rest of Central America; Dominican } \\
\text { Republic; Jamaica; Puerto Rico; Trinidad and Tobago; } \\
\text { Caribbean; Austria; Belgium; Cyprus; Czech Republic; } \\
\text { Denmark; Estonia; Finland; France; Germany; Greece; } \\
\text { Hungary; Ireland; Italy; Latvia; Lithuania; Luxembourg; } \\
\text { Malta; Netherlands; Poland; Portugal; Slovakia; Slovenia; } \\
\text { Spain; Sweden; United Kingdom; Switzerland; Norway; Rest } \\
\text { of EFTA; Albania; Bulgaria; Belarus; Croatia; Romania; } \\
\text { Russian Federation; Ukraine; Rest of Eastern Europe; Rest of } \\
\text { Europe; Kazakhstan; Kyrgyzstan; Rest of Former Soviet } \\
\text { Union; Armenia; Azerbaijan; Georgia; Rest of the World) }\end{array}$ & $\begin{array}{l}\text { aus nzl xoc hkg mng } \\
\text { twn xea xse can usa } \\
\text { mex xna arg bol bra } \\
\text { chl col ecu pry per } \\
\text { ury ven xsm cri gtm } \\
\text { hnd nic pan slv xca } \\
\text { dom jam pri tto xcb } \\
\text { aut bel cyp cze dnk } \\
\text { est fin fra deu grc } \\
\text { hun irl ita lva ltu lux } \\
\text { mlt nld pol prt svk } \\
\text { svn esp swe gbr che } \\
\text { nor xef alb bgr blr } \\
\text { hrv rou rus ukr xee } \\
\text { xer kaz kgz xsu arm } \\
\text { aze geo xtw }\end{array}$ \\
\hline
\end{tabular}

Source: Database GTAP 9.0.

GTAP model represented regional trade level with its instrument. All specification is standard GTAP model with 19 sectors and 16 countries/regions and running with software RunGTAP 3.61. The basic of that country/region aggregation is related with this research topic in ASEAN region. Particularly, data of Myanmar and East Timor are not available in GTAPAgg data. Detail countries/regions aggregation is showed in Table 2 . 
The whole relation that describe the linkages between income and expenditures by any economic agent in the regions (accounting relationship) in GTAP Model was formulated in the equations form. And for the sectors which chosen were 19 sectors of 57 sectors. The sector aggregation can be seen in Table 3.

Table 3. Sector Aggregation Based on GTAP Database

\begin{tabular}{|c|c|c|c|}
\hline No. & Code & Description & Comprising \\
\hline 1. & PDR & Paddy rice & $\mathrm{pdr}$ \\
\hline 2. & WHT & Wheat & wht \\
\hline 3. & GRO & Cereal grains nec. & gro \\
\hline 4. & NGRO & $\begin{array}{l}\text { Vegetables, fruit, nuts; Oil seeds; Sugar cane, sugar beet; } \\
\text { Plant-based fibers; Crops nec. }\end{array}$ & $\begin{array}{l}\text { v_f osd c_b pfb } \\
\text { ocr }\end{array}$ \\
\hline 5. & LVS & $\begin{array}{l}\text { Cattle, sheep, goats, horses; Animal products nec; Wool, } \\
\text { silk-worm cocoons; Meat: cattle, sheep, goats, horse }\end{array}$ & ctl oap wol cmt \\
\hline 6. & LVSP & Raw milk; Meat products nec.; Dairy products & rmk omt mil \\
\hline 7. & FRS & Forestry & frs \\
\hline 8. & FIS & Fishing & fsh \\
\hline 9. & $\begin{array}{l}\text { COL_O } \\
\text { MN }\end{array}$ & Coal; Minerals nec. & coa omn \\
\hline 10. & $\begin{array}{l}\text { OIL_G } \\
\text { AS }\end{array}$ & Oil; Gas & oil gas \\
\hline 11. & MIN & $\begin{array}{l}\text { Petroleum, coal products; Mineral products nec.; Ferrous } \\
\text { metals; Metals nec.; Metal products }\end{array}$ & $\begin{array}{l}\text { p_c nmm i_s } \\
\text { nfm fmp }\end{array}$ \\
\hline 12. & CRP & Chemical, rubber, plastic prods. & crp \\
\hline 13. & OFP & Vegetable oils and fats; Sugar; Food products nec. & vol sgr ofd \\
\hline 14. & PDRP & Processed rice & pcr \\
\hline 15. & $\mathrm{~B}$ - T & Beverages and tobacco products & b_t \\
\hline 16. & $\begin{array}{l}\text { TEX_L } \\
\text { EAT }\end{array}$ & Textiles; Wearing apparel; Leather products & tex wap lea \\
\hline 17. & LUM & Wood products & lum \\
\hline 18. & OMNF & $\begin{array}{l}\text { Paper products, publishing; Motor vehicles and parts; } \\
\text { Transport equipment nec.; Electronic equipment; } \\
\text { Machinery and equipment nec.; Manufactures nec. }\end{array}$ & $\begin{array}{l}\text { ppp mvh otn ele } \\
\text { ome omf }\end{array}$ \\
\hline 19. & SRV & $\begin{array}{l}\text { Electricity; Gas manufacture, distribution; Water; } \\
\text { Construction; Trade; Transport nec.; Sea transport; Air } \\
\text { transport; Communication; Financial services nec.; } \\
\text { Insurance; Business services nec.; Recreation and other } \\
\text { services; PubAdmin/Defence/Health/ Educat; Dwellings }\end{array}$ & $\begin{array}{l}\text { ely gdt wtr cns } \\
\text { trd otp wtp atp } \\
\text { cmn ofi isr obs } \\
\text { ros osg dwe }\end{array}$ \\
\hline
\end{tabular}

Source: Database GTAP 9.0.

\section{Result and Discussion}

Gravity Model Estimation. Those coefficient estimations were run by some time and it is the best model. All variables as proxy of GDP Indonesia and trading partners, distance, population, tariff, price, and capital labor have tried to re-specification. All sign of variables is fit in with theory. The estimation results of equation (1) and obtained with the PPML Model for rice trade analysed are presented in Table 4.

Based on RESET test, PPML method was robust for estimating Gravity Model. The RESET test value is 1.13 and it is higher that probability value of $\mathrm{Chi}^{2}(=0.2874)$. Besides being consistent in the presence of heteroscedasticity, this method also provides a natural way to deal with zero values of 
the dependent variable (Silva and Tenreyro, 2006). Import as dependent variables have some zero value because of not all country occurs rice trade.

In order to see whether all variables can explain the model, the $\mathrm{R}^{2}$ value is needed. $\mathrm{R}^{2}$ value is 0.989 shows that overall model can be explained by its variables $98.9 \%$, while the rest $1.10 \%$ described by other variables from out model. And in order to see whether each variable can influence the dependent variable, it is able to be checked from $\mathrm{z}$ value comparing with prob. value (significant level). There are 3 (three) variables statistically influence rice import, namely ratio GDP Indonesia and trading partner, distance, and dummy ASEAN as member country.

Table 4. Coefficient Estimation Result of Gravity Model with PPML Method

\begin{tabular}{|l|l|c|c|c|}
\hline \multicolumn{1}{|c|}{ Variables } & \multicolumn{1}{|c|}{ Description } & \multicolumn{1}{c|}{$\begin{array}{c}\text { Coefficient } \\
\text { Estimation }\end{array}$} & $\mathrm{z}$ & $\mathrm{P}>|\mathrm{z}|$ \\
\hline lgdpod & $\begin{array}{l}\text { Log ratio GDP of origin and } \\
\text { destination country }\end{array}$ & 1.30 & $1.83^{* *}$ & 0.068 \\
\hline ldis & Log distance between country & -8.70 & $\begin{array}{c}1.99^{* *} \\
*\end{array}$ & 0.047 \\
\hline lmtro & Log rice tariff between country & -0.30 & -1.15 & 0.250 \\
\hline lincm & $\begin{array}{l}\text { Log income per capita between } \\
\text { country }\end{array}$ & -0.01 & -0.15 & 0.878 \\
\hline lpo & Log price at origin country & 0.25 & 0.21 & 0.837 \\
\hline lpd & Log price at destination country & 1.97 & 0.75 & 0.452 \\
\hline lvkblo & $\begin{array}{l}\text { Log capital labor ratio of origin } \\
\text { country }\end{array}$ & -0.13 & -0.04 & 0.969 \\
\hline $\begin{array}{l}\text { Log capital labor ratio of destination } \\
\text { lvkbld }\end{array}$ & -3.41 & -0.84 & 0.403 \\
\hline dasean & Dummy ASEAN & -15.10 & $-1.40^{*}$ & 0.163 \\
\hline $\begin{array}{l}\mathrm{R}^{2}=0.989 \\
\text { Pseudo log-likelihood: }-1355.6662\end{array}$ \\
$\begin{array}{l}\text { Number of parameters: } 168 \\
\text { Number of observations: } 477 \\
\text { RESET test: chi2(1) }=1.13, \text { Prob }>\text { chi2 }=0.2874 \\
\text { Endogenous variable: import between country (in level) }\end{array}$ & & & \\
\hline
\end{tabular}

Note: $* * *, * *$, and $*$ : indicate significant at $\alpha=5 \%, 10 \%$, and $20 \%$, respectively.

Source: author, 2018.

The estimation results known that every increasing in ratio GDP Indonesia and trading partner of 1\% so the import quantity of Indonesia would increase by $1.30 \%$ assuming ceteris paribus. This result is in line with some of researcher, which are Sari and Widyastutik (2015) and Rahmah (2016).

Second variable that influence rice import is distance as proxy of transportation costs. It has a negative and significant impact. If there is increasing in distance of $1 \%$, it would have sent down the rice import volume of Indonesia about $8.70 \%$ assuming ceteris paribus. It is caused farther the distance then larger in cost of transportation. As general, this result is in line with some of research result, which are Fontagné, et al (2016), O'Callaghan and Uprasen (2008), and Silva and Tenreyro (2006). And the last variable, dummy ASEAN also influence rice import. When the country is member of ASEAN then her import will decrease of $15.10 \%$ assuming ceteris paribus. This has happened because of rice is traded specifically, not all ASEAN member country always import from major countries (Thailand and Vietnam), but also from India, China, and Japan. 
Calculating Rice Non-Tariff Measures. The result of tariff equivalents of rice NTMs is presented in Table 5. The country of being used as a benchmark in the tariff equivalence calculation is Singapore against rest of the world. They have the relative low difference value between trade actual and trade potential or we can say that both of them have the small trade barrier or trade restriction in rice.

The value of tariff equivalence on rice NTMs are vary between countries, from 3.43\% until 41.76\%. The highest value is Brunei Darussalam and the lowest value is Japan. In Brunei Darussalam, Elizabeth (2016) explain there are 58 NTM regulations containing NTMs, but only 2 (two) that have been notified to the World Trade Organization (WTO), namely the Public Health (Food) Regulations and the Halal Meat Rules. The total number of coded NTMs is 516, affecting 5,613 products (HS code) or $56.6 \%$ of the total products traded in Brunei, included food.

Various types of NTMs and product specific NTMs are practiced by Japan, which are tariff quota, state trading, and state procurement which are imposed mainly on tobacco, raw sugar and cereal products. Deb (2007) said among the countries studied, NTMs coverage for agricultural products is highest in India and followed by Japan. But in this research, Japan relatively has low NTMs value, particular in rice. As reported from University of Southern California (2016) research indeed Japan has low until moderate level of NTMs, namely in regulatory philosophy, TBT, SPS, state of information, transport infrastructure, administrative burdens, and consistency of enforcement, exception in level of protectionism. The result maybe is difference because the approach used is deference too.

The staple products, including rice, are some of the most contentious products traded across commodities. The presence of specific government agencies that oversee rice in some economies speaks to how critical grains are to national interests. Similar to fresh produce, the products often need to meet strict SPS and TBT regulations that may go beyond what is necessary to protect consumers. The risk of spoilage is typically lower. On the other hand, many grain traders are charged with purchasing buffer stock or acquiring special import licenses, which carry their own administrative and logistical burdens. While the risk might be comparatively lower, this category typically calls for additional procedures for a business to successfully trade (University of Southern California, 2016).

Table 5. The Tariff Equivalents of Rice NTMs (\%)

\begin{tabular}{|c|c|c|c|}
\hline No. & Region & Country & Average \\
\hline 1. & \multirow{9}{*}{ ASEAN } & Brunei Darussalam & 41.76 \\
\hline 2. & & Indonesia & 26.07 \\
\hline 3. & & Cambodia & 33.75 \\
\hline 4. & & Lao & 10.22 \\
\hline 5. & & Malaysia & 11.43 \\
\hline 6. & & Philippines & 20.82 \\
\hline 7. & & Singapore & 8.43 \\
\hline 8. & & Thailand & 34.09 \\
\hline 9. & & Viet Nam & 33.24 \\
\hline 10. & \multirow{3}{*}{ Middle and East Asia } & China & 21.39 \\
\hline 11. & & Japan & 3.43 \\
\hline 12. & & Korea & 33.63 \\
\hline 13. & \multicolumn{2}{|l|}{ South Asia } & 25.03 \\
\hline 14. & \multicolumn{2}{|l|}{ Sub-Sahara Africa } & 23.30 \\
\hline 15. & \multicolumn{2}{|l|}{ Middle East Asia } & 26.48 \\
\hline 16. & \multicolumn{2}{|c|}{ Rest of the World (ROTW) } & 23.02 \\
\hline
\end{tabular}

Source: author, 2018. 
Indonesian rice trade opened is relative low level and that value is average range where another ASEAN member country applied. Even Indonesia's value is relatively lower then with rice NTM Thailand and Vietnam, as main rice exporter country. Thailand's major NTMs are related to import license, technical measures, and quantity control.

In the ASEAN region, commitment on rice trade has been carried out through ASEAN Trade in Goods Agreement (ATIGA), where each ASEAN country has the tariff decreasing schedule. It is parallel with ASEAN Economic Community (AEC) where the ASEAN Member States (AMS) took their most important stride towards deeper and more lasting regional economic integration. In the first of four pillars of AEC, the AMS aim to transform the region's economies into one single market and production base by 2015. Particularly in food security and trade, there is The ASEAN Food Security Reserve Board (AFSRB) and it harnesses both sides of the region's food markets to work together to avoid extreme price volatility, or to mitigate any adverse effects of temporary food shortages (ADB, 2015).

A big challenge comes from food national interest each ASEAN country against food regional achievement. On the other hand, there is a potential option that can still be developed, namely regional rice stocks or called ASEAN Plus Three Emergency Rice Reserve (APTERR). It is an essential option how to reduce fluctuations in rice prices that many ASEAN country fear when fully rice trade liberalization will conduct.

Impact on Indonesian Food Security. Table 6 is presented the impact of ASEAN rice NTMS on Indonesian food (rice) security. There is 2 (two) scenario simulation, namely imposing ASEAN rice NTMs and fully rice trade liberalization as controlling scenario.

Table 6. The Impact of ASEAN Rice NTMs on Indonesian Food (Rice) Security $(\Delta \%)$

\begin{tabular}{|c|l|c|c|c|c|c|}
\hline \multirow{2}{*}{ No. } & \multirow{2}{*}{ Simulation } & \multicolumn{3}{|c|}{ Availability } & \multirow{2}{*}{ Utility } & \multirow{2}{*}{ Accessibility } \\
\cline { 3 - 5 } & & Production & Export & Import & & \\
\hline 1. & Imposing NTMs & 2.995 & 59.605 & -32.808 & -0.495 & 1.736 \\
\hline 2. & Trade Liberalization & -1.027 & -13.184 & 12.430 & 0.164 & -0.599 \\
\hline
\end{tabular}

Note: Simulation 1: NTM is obtained from Gravity Model, 2018.

Simulation 2: all ASEAN country have zero tariff in rice.

When ASEAN rice NTMs is imposed, it will make Indonesian food (rice) security become worse off in general. On the rice availability declines because of rice import goes down and a little bit raise in domestic rice production. In terms of rice utilization also declines when rice price increase. Rice NTMs will add costs and stimulate increase in rice price, so finally rice accessibility will decline. So, what about the simulation of ASEAN rice trade fully liberalized? In general, this scenario actually makes Indonesian food (rice) security become better off that rice availability, rice utility, and rice accessibility increases. But what needs to be noted here is that simulation pushes to decrease domestic rice production. This is not surprising because basically Indonesian rice does not have a comparative advantage in international market (Azahari dan Hadiutomo, 2013). These conditions are becoming more complicated and having polemic potential in the community because of the divergent opinions. Some people view the success of food security is measured by the achievement food (rice) selfsufficiency and others see that the success should be assessed by the achievement food (rice) availability. This is in accordance with the basic explanation by Food and Agriculture Organization (FAO), related to food policy each country in the world are faced with options to achieve food selfsufficiency or food self-reliance or food availability term through food trade. 


\section{Conclusion}

This research concluded that rice NTMs imposes by all ASEAN member country with vary value, including Indonesia. Brunei Darussalam, Thailand, and Cambodia have the highest rice NTMs based on estimation of tariff equivalent calculation. Even though rice tariff tends to decrease with regional agreement but rice NTMs become new challenge and also alternative option how to deal with domestic protection.

Imposing ASEAN rice NTMs lead to negative effects on Indonesian food security through rice availability, utility, and accessibility. In other hand, rice NTMs policy would also improve rice production because of higher rice price is positive incentive for rice farmer to produce. The contrary situation happened when fully rice trade liberalization is conducted. It would increase all food (rice) security indicators, include rice import. So, there is trade-off between NTMs and fully rice trade liberalization policy. The government should be wise and careful when imposing rice NTMs as temporary policy to stimulate rice self-sufficiency.

\section{References}

Akhvlediani T. and Śledziewska, K. (2017). Implications of the European integration: revisiting the hypothesis of 'hub-and-spokes' model. Baltic Journal of Economics, 17:1 pp. 45-56.

ADB. (2015). ASEAN Food Trade Forum: How Can ASEAN Become More Resilient to Food Crises Under the ASEAN Economic Community? ASEAN Food Security Reserve Board, Malaysia (https://www.adb.org/sites/default/files/related/36183/aftf-overview. pdf).

APEC. (2014). Perceptions on the Use of Non-Tariff Measures Within the APEC Region. AsiaPacific Economic Cooperation Policy Support Unit, Heng Mui Keng Terrace.

Azahari, D. H. dan Hadiutomo, K. (2013). Analisis Keunggulan Komparatif Beras Indonesia. Analisis Kebijakan Pertanian. Vol. 11, No. 1, hal. 61-73.

Deb, U. K. (2007). Non-Tariff Barriers in Agricultural Trade: Issues and Implications for Least Developed Countries. ARTNeT Policy Brief No. 12. ARTNet and UNESCAP.

Elisabeth, C. R. (2016). Classification of Non-Tariff Measures in Brunei Darussalam. In Ing, L. Y., S. F. de Cordoba, and. O. Cadot (Eds.). Non-Tariff Measures in ASEAN. ERIA Research Project Report 2015-1, Jakarta: ERIA, pp. 37-49.

Fontagné, L., Mitaritonna, C., and Signoret, J. (2016). Estimated Tariff Equivalents of Services NTMs. CEPII Working Paper.

Gao, Q., Ito, S., Ogundari, K., and Saito, H. (2016). Evaluating Welfare Effects of Rice Import Quota in Japan: Based on Measuring Non-Tariff Barriers of SBS Rice Imports. Sustainability, 8, 817, pp. $1-13$.

Gourdon, J. (2014). CEPII NTM-MAP: A Tool for Assessing the Economic Impact of Non-Tariff Measures CEPII Working Paper No. 24. Centre d'Etudes Prospectives et d'Informations Internationales.

Goyal, T. M., Mukherjee, A., and Kapoor, A. (2017). India's Exports of Food Products: Food Safety Related Issues and Way Forward. Working Paper No. 345. Indian Council for Research on International Economic Relations.

Marks, S. V. (2017). Non-Tariff Trade Regulations in Indonesia: Nominal and Effective Rates of Protection. Bulletin of Indonesian Economic Studies, Vol. 53, Issue 3, pp. 333-357.

O'Callaghan, B. A. and Uprasen, U. (2008). Impact of the $5^{\text {th }}$ EU Enlargement on ASEAN. A paper presented at the EcoMod International Conference on Policy Modelling, Berlin, Germany, $2^{\text {nd }}$ $-4^{\text {th }}$ July 2008.

Park, Soon-Chan. (2002). Measuring Tariff Equivalents in Cross-Border Trade in Services. KIEP Working Paper 02-15, Korea Institute for International Economic Policy.

Rahmah, K. N. (2016). Trade Flows Analysis and The Role of Standards on Canned Tuna Trade. Tesis. Bogor: Institut Pertanian Bogor. 
Sari, K. R. dan Widyastutik. (2015). Faktor yang Mempengaruhi dan Estimasi Tarif Ekuivalen NTBs Ekspor Kayu Lapis Indonesia. Buletin Ilmiah Litbang Perdagangan, Vol. 9. No. 1, hal. 95-108.

Silva, J. M. C. S. and Tenreyro, S. (2006). The Log of Gravity. The Review of Economics and Statistics, Vol. 88, No. 4, pp. 641-658.

University of Southern California. (2016). Non-Tariff Barriers in Agriculture and Food Trade in APEC: Business Perspectives on Impacts and Solutions. APEC, APEC Business Advisory Council, and University of Southern California.

UNCTAD. (2015). International Classification of Non-Tariff Measures, 2012 Version. New York and Geneva: United Nations Conference on Trade and Development.

Walmsley, T. L, and Minor, P. (2015). Willingness to Pay in CGE Models (Impact ECON Working Paper No. 04). Impact ECON: Boulder, CO, USA.

Wall, H. J. (1999). Using the Gravity Model to Estimate the Costs of Protection. Federal Reserve Bank of St. Louis Review, pp.33-40.

Westerlund, J. and Wilhelmsson, F. (2011). Estimating the Gravity Model without Gravity Using Panel Data. Applied Economics, 43, pp. 641-649. 